\title{
Biblical hypotexts in Prudentius' Contra Symmachum
}

\author{
Case study of C. Symm. II.95-96*
}

Prudentius' Contra Symmachum is a poem set against the literary backdrop of the dispute between the prefect of the city of Rome and Ambrosius, bishop of Milan, over the removal of the altar dedicated to the goddess Victory. In 384, Symmachus addressed for the third time a relatio -on this occasion to young emperor Valentinian III- in order to, among other issues, restore the ara Victoriae to its former place in the Roman curia after its removal by Constantius II in 357. To this, Ambrose reacted also by addressing two epistles to Valentinian (Epistulae 17 and 18). In the latter he specifically rebukes the main points in Symmachus' relatio; thereby, the prefect's intentions were once again thwarted.

As for Prudentius' answer in Contra Symmachum, there is growing consensus among scholars against the hypothesis of the poem having been prompted by a new intent on Symmachus' part (in Honorio regnante) of restoring pagan privileges, lost in 402 when Alaric's vandals had already set foot on Italian soil. Among the academics who share the opinion that the conflict involving Symmachus was by then already a matter of the past, some consider that Prudentius addressed the issue once more because he did not find the answer provided by Ambrose convincing enough. ${ }^{1}$ Others, on their part, think that Prudentius refutes Symmachus as some sort of indirect reaction against certain pagans who, at the time - like Claudian -, interpreted Stilicho's victory against Alaric in the Battle of Pollentia (402) as a victory of pagan Rome, still protected by the gods. ${ }^{2}$ From this perspective, Contra Symmachum would not be a pertinent answer to an already old conflict, but the literary result of a highly charged spiritual environment that had wrought a fragile peace for the Empire, and even more so for Italy. ${ }^{3}$

Therefore, the pagan exaltation of Victory would exceed the occasional dispute to expose, as Lavarenne points out, "l'idéologie triomphaliste de l'Empire théodosien et une certaine philosophie chrétienne de l'histoire qui, s’inspirant de la pensée d'Eusèbe de Césarée, annonce, avant la synthèse augustinienne de la Cité de Dieu, la conception d'un Bossuet sur l'histoire universelle". ${ }^{4}$

\footnotetext{
* English translation of Carmen Pulín Ferrer.

1 Fernández Vallina (1989) 249.

2 Claud. Get. 571-573 (Hall, Teubner): Romanum reparate decus molemque labantis| imperii fulcite umeris: hic omnia campus| uindicat, haec mundo pacem uictoria sancit.|

3 Garuti (1996) 24.

4 Lavarenne (1992) 95.
} 
Besides, Danuta Shanzer, who has studied the composition process of Contra Symmachum, concludes that its first part was written mainly during Theodosius' rule, in 394, whereas the complete work -rewritten, amplified and unified- was not issued until 402-403. These data allow us to maintain that Prudentius' Contra Symmachum is a literary work on an old issue (the apologetic debate) that was published on a new historical occasion (the instability caused by Alaric). ${ }^{5}$

The writing, ultimately addressed to young emperor Honorius, consists of two books: the first of them is a refutation of pagan polytheism, followed by an eulogy of Theodosius' religious policy, which put an end to paganism and reduced its stubborn followers, represented by Symmachus, to a minority. ${ }^{6}$ The second and longer one refutes each and every argument provided by Symmachus in his Relatio tertia (Rel. 3). Its main point is that the cause of Rome's military success is not the goddess Victory, but an effort on the part of its soldiers, assisted by the one true God. ${ }^{7}$ Six arguments by Symmachus are then addressed and refuted one by one: a) the pagan religious tradition is set in opposition to the new faith, which is seen as a positive evolution; ${ }^{8}$ b) Rome's destiny is permanence, sustained by Christ; ${ }^{9}$ c) the prosperity and the unification of many peoples attained by Rome were not caused by the gods, but meant as a preparation for the coming of Christ; ${ }^{10} \mathrm{~d}$ ) Rome is no longer a white-haired city, claiming for its lost freedom; it has been rejuvenated under the Christian empire and God's protection, and the victory at Pollentia undeniably proves it; ${ }^{11}$ e) as for the religious tolerance claimed by Symmachus, who argues that there are many paths leading to the knowledge of the mystery of God, Prudentius answers that against the path of idolatry, which leads to hell, only the path of God's truth, revealed by the Christian faith, is valid; ${ }^{12}$ f) Rome's famines do not come as a revenge of the gods after the Vestals had their allowance withdrawn; besides, their virginity is not praiseworthy, because it is only temporary, and these women do also show their harshness at gladiatorial combats, an entertainment which Prudentius suggests to suppress for good. ${ }^{13}$

Overall, the second book of Contra Symmachum runs parallel to Ambrosius' answer in his Epistula 18 to the pagan nobleman; this latter writing does also follow the order of the argumentation in the Relatio tertia by Symmachus. Nevertheless, it is clear that the work of Prudentius is more extensively developed when compared to the basic arguments provided by Ambrose. One of them is the answer to the religious

5 Shanzer (1989) 458-462.

6 The outline of contents suggested below follows Lavarenne (1992) 91-93.

7 C. Symm. 5-66 (Cunningham, CCSL 126) and Rel. 3.3 (Zelzer, CSEL 82.3).

8 C. Symm. 91-369 and Rel. 3.3-4.

9 C. Symm. $370-487$ and Rel. 3.8.

10 C. Symm. 488-640 and Rel. 3.8-9.

11 C. Symm. 641-772 and Rel. 3.9-10.

12 C. Symm. 773-909 and Rel. 3.10.

13 C. Symm. $910-1132$ and Rel. 3.11-17. 
relativism proposed by Symmachus. ${ }^{14}$ It should be noted that the pagan, an excellent orator, argued that there are many ways, many religious perspectives, to disclose the mystery which transcends man. His argument for justifying his relativism is that if every man can enjoy the goods of creation, then also every man can find the mysterious truth of what transcends mankind, even by following different paths (Rel. 3.10):

Eadem spectamus astra, commune caelum est, idem nos mundus inuoluit; quid interest qua quisque prudentia uerum requirat? Uno itinere non potest perueniri ad tam grande secretum. Sed haec otiosorum disputatio est; nunc preces, non certamina offerimus.

Ambrosius' answer (Epistula 18.8), built on elements typical of the genus epidicticum, based on a rhetorical swaying between praise and vituperation, directly opposes the faith of Symmachus to that of the Milanese bishop, and displays contrasting concepts against the former and in support of the latter: ignorance - knowledge; conjecture - certainty; religiousness against revelation. ${ }^{15}$ At the end of the paragraph, Ambrosius draws a distinction between pagan religion and the theodicy practiced by philosophers, and uses them for arguing that even they have laughed at polytheism and the worship of the gods:

Uno, inquit, itinere non potest perueniri ad tam grande secretum. Quod uos ignoratis id nos dei uoce cognouimus, et quod uos suspicionibus quaeritis nos ex ipsa sapientia dei et ueritate compertum habemus. [...] Denique etiam ipsi philosophi uestri ista riserunt.

In short, Ambrose succinctly answers discrediting Symmachus' relativist religiosity against the revealed certainty of the fides catholica.

As for Prudentius, he creates a fictitious Symmachus in Contra Symmachum, and discusses with him using arguments taken from the Relatio 3, written by the prefect in 384, as already said. This composition device enlivens the discussion. More specifically, Prudentius' answer to the argument used by Symmachus in his Relatio 3.10 appears in three different places. The fact that he addresses the issue thrice reveals that the main question of Symmachus' Relatio 3.10, where he defends the existence of many ways to meet the mystery transcending mankind, is for Prudentius one of the main points to be refuted in his poem. ${ }^{16}$ My analysis will be focused on the first of them.

The first refutation appears at the beginning of the second book. Prudentius answers to his fictional Symmachus, who, making Rome speak in his support, ends his allegation as follows:

14 Ambrosius states that there is only one true religion and one path leading to the mystery of God, against a religious pluralism covering a relativistic position. (Moreno [2002]).

15 Ambrosius' rhetorical pattern does certainly remind of Lactantius' Inst. VII.8.3: nos igitur certioribus signis eligere possumus ueritatem, qui eam non ancipiti suspicione colligimus, sed diuina traditione cognouimus.

16 C. Symm. II.85-90; 773-774; 843-846 
Vno omnes sub sole siti uegetamur eodem
aëre; communis cunctis uiuentibus aura;
sed qui sit qualisque Deus, diuersa secuti
quaerimus, atque uiis longe distantibus unum
imus ad occultum: suus est mos cuique genti,
per quod iter properans eat ad tam grande profundum. ${ }^{17}$

It must be noted that in the Relatio 3 the historical Symmachus does not question the nature (in singular) of God; this seems quite logical, as his perspective on the transcendental mystery is a polytheistic one. But Prudentius' fictitious Symmachus does actually put the question through Rome itself: qui sit qualisque Deus. ${ }^{18}$ Nevertheless, this issue does not appear as such among several interests displayed by Symmachus in his Relatio 3. The pagan text offers -but for the use of the singular mens divina ${ }^{19}$ all sort of polytheistic references: fatales genii, dei patrii, numina. However, Prudentius transforms the thesis sustained by the real Symmachus -the defense of religious relativism on the issue of the truth about the mystery transcending man- to address quite a different question, the possibility of knowing the mystery of the sole god by different paths provided by reason:

His tam magnificis tantaque fluentibus arte respondit uel sola fides doctissima primum pandere uestibulum uerae ad penetralia sectae. Nam cum diuinis agimus de rebus, et illum qui uel principio caruit uel fine carebit quique chao anterior fuerit mundumque crearit coniectare animo contendimus, exigua est uis humani ingenii tantoque angusta labori.

Quippe minor natura aciem si intendere temptet acrius ac penetrare dei secreta supremi, quis dubitet uicto fragilem lassescere uisu uimque fatigatae mentis sub pectore paruo turbari inualidisque hebetem subcumbere curis? sed facilis fidei uia prouocat omnipotentem credere, qui bona non tantum praesentia donat, sed uentura etiam longisque intermina saeclis promittit...20

17 C. Symm. II.85-90: "We all draw life from the same atmosphere under the same sun, all living beings share the same air; but we follow different paths when we inquire into the being and nature of God, and by ways far apart approach the same secret; every race has its own custom, and that is the line along which it must hasten to reach the great mystery" (Thomson (1953)).

18 C. Symm. II.87.

19 Rel. 3.8.

20 C. Symm. II.91-107: "To these fine words flowing with such art Faith has given the answer, for she before all has skill to open the first approach to the heart of the true belief. For when we are concerned with divine things and striving to reach a conception of Him who was without beginning and will be without end, who existed before the primeval darkness and created the world, the 
Manipulating Symmachus' ipsissima verba, Prudentius changes a debate where arguments defending monotheism against polytheism were expected, transforming it in a defense of the Christian faith, the only one that truly answers to the mystery of God. Prudentius justifies acting like this due to his own opponent, as Symmachus, in his Rel. 3.10, does not make a defense of polytheism, but of relativism as an option to disclose the transcendent mystery. To this proposal, based on the multiplicity of paths to seek God (C. Symm. II.87-88 diversa sequi, viae distantes), Prudentius answers that only faith teaches exclusively (sola fides doctissima) the secrets of the true doctrine (vera secta), which is also liberating (libera secta, C. Symm. II.486 ${ }^{21}$ ), for not only does it bestow present goods, but also everlasting ones in the future (bona praesentia; ventura et intermina, will he say later in C. Symm. II.105-106). The path of the faith received by Christians enables to meet easily (facilis fidei via) the mystery of God, which, by its same nature, exceeds human intents of disclosing it on its own (exigua est vis). He will later affirm that, being that mystery so grand, its knowledge via the Christian faith makes reasonable the truthfulness of what faith allows us to know about the truth on God and His promises. ${ }^{22}$

But most interesting for our investigation is that, in these verses, Prudentius not only defends the way of revelation (fides) against the many paths supported by Symmachus, as Ambrosius had already done in his epistle (384), but also answers the quaestio principalis of "his" Symmachus: the one which specifies the content of the grande secreto formula in the writing by the real Symmachus, implicitly raising the issue of the true nature of God: qui sit qualisque deus (C. Symm. II.87). Prudentius answers to this question right at the beginning of his confutation: the god about whom "his" Symmachus asks is both eternal and creator (C. Symm. II.95-96).

Prudentius is linking here two aspects highlighting both God's might -displayed in the visible creation (mundus) - and His greatness, which can comprehend and overcome time. This greatness is described in a twofold formula, in order to express that God surpasses time boundaries, as in time there is a before and an after. But he also adds a peculiar point by alluding to chaos, something that not only connects God's greatness to His creative powers but could also be hinting at a biblical back-

\footnotetext{
force of the human mind is too petty and limited for so great a task. If the lesser nature seek to strain its gaze too keenly and to penetrate the mystery of the most high God, who would question that its vision is beaten, its frail power flags, the working of the tired intellect is thrown out in the little mind and is dulled and fails under its feeble efforts? But the easy way of faith calls to believe that the Almighty is He who not only grants us blessings for the present time but promises blessings to come, that will last without end through the long ages, so that I shall not wholly pass away into empty nothingness and perish after a brief enjoyment of the light" (Thomson (1953)).

21 It is really symptomatic how Prudentius takes up here every issue in Symmachus' argumentation and turns them into an exhortation to conversion: Huc ades omne hominum genus, huc concurrite et urbes!| lux inmensa uocat, factorem noscite uestrum!| libera secta patet. (C. Symm. II.484-486).

22 C. Symm. II.120 -124: Hac ratione fides sapienter conicit, immo| non dubitat uerum esse deum qui quod sumus et quod| uiuimus inlaesum semper fore, si mereamur,| nos sperare iubet. Cf. Evenepoel (1991) 322-324.
} 
drop for this couple of verses, as we intend to prove in this paper. The expressions employed by Prudentius in his definition of God -beginning and end (principio caruit uel fine carebit); the allusion to chaos (chao anterior fuerit); the creation of the world (mundumque crearit) - will act as guidelines in our study.

We will start with the details provided by the leading scholars that have addressed Contra Symmachum. To the question of a possible biblical base underlying C. Symm. II.95-96 there is no positive answer to find when consulting the most relevant critical editions, both old ${ }^{23}$ and more recent $\left(20^{\text {th }}\right.$ century) ${ }^{24}$ Searching the annotated translations ${ }^{25}$ and partial commentaries ${ }^{26}$ does shed a more promising light, as will be shown.

In the first place, the idea of human intelligence being able by itself to comprehend God's mystery could have a rather vague biblical basis on Proverbs 25:27 and Ecclesiasticus 3.22 for C. Symm. II.97-98. ${ }^{27}$ By quoting Wisdom 9:16 we could be treading on more solid ground, as there are coincidences to be found both in theme and vocabulary ${ }^{28}$. The second notion, ex nihilo creation in two stages -creation of chaos and later creation of cosmos (C. Symm. II.96)- would find an imprecise coincidence in Genesis 1.1- $2^{29}$. In this verse by Prudentius, the use of the word chaos could also be referencing the Greek version of Wisdom $11.17 .^{30}$ The third idea, divinity being previous (and therefore eternal) to creation, and also its foundation, has a plausible biblical basis in Colossians 1.17, as noted by Brown (2003). ${ }^{31}$ We must also point out that this scholar does not justify proposing a quote attributed to Christ as scriptural reference for a text which apparently makes reference to an eternal, creator God, who could be seemingly identified with the Father in Christian theology. Nevertheless, his answer could be based on Prudentius' vague mention of a diuinae

23 Langen (1497), Arévalo (1789), Orbarius (1845), Dressel (1860).

24 Bergman (1926), Cunningham (1966) and the 1983' revision, Lavarenne (1992).

25 Lanfranchi (1898), Thomson (1953), Guillén (1959), Rivero (1997), Ortega and Rodríguez (1981), Brown (2003).

26 Middeldorpf (1823), Pascual (1976), Brown (2003), Tränkle (2008).

27 For exigua est uis humani ingenii (C. Symm. II.97-98), Lanfranchi (1898) and Guillén (1959) find reference in Prov 25.27 (Sabatier, Vetus Italica: Sicut qui mel multum comedit, non est ei bonum: sic qui scrutator maiestatis, opprimetur a gloria). On his part, Guillén (1959): Eccl 3.22 (Vetus Latina, Beuron edition: quae praecepit tibi Deus illa cogita semper et in pluribus operibus eius ne fueris curiosus). 28 Lanfranchi (1898) and Guillén (1959) connect C. Symm. II.97-98 to Sap 9.16 (Vetus Latina, Beuron edition: difficile aestimamus quae in terra sunt et quae in prospectu sunt inuenimus cum labore; quae in caelis sunt autem quis inuestigabit?). It is reasonable to think that labore, in caelis, inuestigabit can justify the scriptural substratum of C. Symm. II.94 and, in particular, of C. Symm. II.97-98.

29 Cf. Vetus Latina, Beuron edition: In principio fecit Deus caelum et terram. Terra autem erat inuisibilis et inconposita (textual variant: informis). This reference is given by Pascual (1976).

30 Cf. Middeldorpf (1823), Pascual (1976) give for C. Symm. II.96 the scriptural hypotext Sap 11.17 (Vetus Latina, Beuron edition: omnipotens manus tua quae creavit orbem terrarum ex materia invisa). The formula materia invisa has a textual variant, informi materia; which corresponds literally with the



31 Cf. Col 1.17 in Sabatier, Vetus Latina: et ipse est ante omnes, et omnia in ipso constant. 
res, ${ }^{32}$ although this is by no means justification enough. Also, the notion of creation in Colossians 1.17 does not have Christ as a subject, and, if literally taken, is of no use in order to justify mundum crearit, an expression which shares the same subject with the remaining verbs in C. Symm. II.95-96. On our side, leaning also on the vague semantics of diuina res, we consider that the idea of divinity being prior to creation (and, therefore, eternal) could also find echo in Proverbs 8.22-29, ${ }^{33}$ but neither does this quote allude to the Father, but to Wisdom, usually identified in Christian tradition with the Son. Moreover, in these verses of Proverbs creative action does not appear, albeit being present in C. Symm. II.96.

We will try to overcome these difficulties by looking at other loci in Prudentius' poetry and in other non-prudentian testimonies. There are two passages by Prudentius which present some formal coincidences with C. Symm. II.95-96. The first one is in Contra Symmachum I.325-327; there, against those who dare to consider the Sun a god, the author presents the true God as He who is greater than matter and has no end, fine caret:

ille deus uerus quo non est grandior ulla materies, qui fine caret, qui praesidet omni naturae, qui cuncta simul concludit et inplet.

In Cathemerinon 4.7-9 we can also find an invocation describing God Sabaoth, everlasting spirit, devoid of beginning and end (expers principii, carensque fine), and creator of the world (rerum conditor):

Hic est quem sabaoth deum uocamus;

expers principii carensque fine,

rerum conditor et repertor orbis,

Along with these testimonies we do find two further passages also displaying formal parallelisms, but now the one depicted as eternal is not God, but the Word. The first of these passages, excerpted from Apotheosis 264-267, is put in a context thematically close to C. Symm. II, the present object of our study. There it is claimed that, by following the path of reason (cum uentum [...] ad normam rationis et $\operatorname{artis}^{34}$ ), human nature is able to recognize a mighty supreme being. ${ }^{35}$ But it is difficult for the human mind to go further, to disclose the hidden secrets of God's mystery before

32 C. Symm. II.94.

33 Cf. Prov 8.22-25 in Sabatier, Vetus Latina: Dominus condidit me initium [textual variant: in initio] uiarum suarum in opera sua. Ante saeculum fundauit me: in principio antequam terram faceret et antequam abyssos constitueret, priusquam procederent fontes aquarum, antequam montes conlocarentur, ante omnes colles genuit me...

34 Apoth. 207.

35 Apoth. 212-214: Non recipit natura hominis (modo quadrupes ille/ non sit et erecto spectet caelestia uultu)| non recipit neget ut regimen pollere supremum.| 
the beginning of the world..$^{36}$ Only transmitted faith ${ }^{37}$ allows mankind to know how the Father begot the beginningless Word. It is this transmitted faith what enables us to overcome the handicap of facing the mystery of God by sole reason; the main issue in this mystery is the trinitary intradivine life or, more specifically, the relationship between Father and Son, between God and His Word:

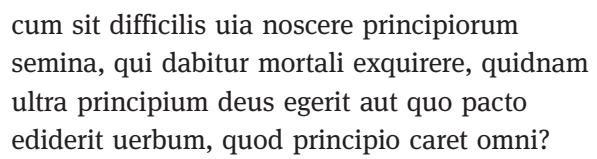

In this excerpt we can find the notion of the strenuous search of God (difficilis, exquirere); that of existence before time, now referred to the generation of the Word (ultra principium egerit aut ediderit), and, thirdly, the idea of timelessness (principio caret omni), also applied to the Word in an expression identical to that in C. Symm. II.95.

The second testimony, taken from Cathemerinon 12.37-40, contains quite significant parallels with our passage: the idea of searching -which, in this case, has vision (cernere) as a consequence- and the notion of eternity, also based on two temporal limits: endlessness (nesciat finem pati) and, on the other hand, existence before heaven and chaos (antiquius caelo et chao). This is the one text among those by Prudentius which offers the closest parallel to the formula chao anterior fuerit in the distich object of this study. Those verses refer to the Christ, sidus aeternum, king of the Gentiles, beheld as Sun of Justice by the stargazing Magi. This king, states Prudentius, is older than heaven and chaos, he is also eternal (interminum; aeternum manet $^{38}$ ) and not subjected to the limits imposed by time.

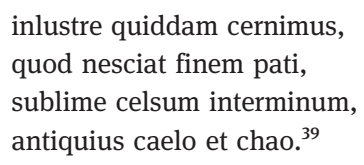

Ante chaos existence of the Verb is connected in another passage by Prudentius to His generation $a b$ aeterno in the bosom of the Father with the expression ante chaos genitus (Hamart. 44). The idea of being prior to chaos could also be alluding to the concept in Hesiod's Theogony, where chaos is the origin of cosmos and of the subsequent genealogies of gods. ${ }^{40}$ It is also possible that Prudentius had in

36 Apoth. 259-263.

37 Cf. traditur in Apoth. 268.

38 Cath. 12.17.

39 Cath. 12.37-40.

40 Hesiod. Theog. 115. Kayser (1881), 313, shows that the shapeless, chaotic mass, the Hebrew thohu wa bohu in Genesis 1:2, is sometimes associated by Christians to cosmological descriptions they read 
mind Lactantius' critic to the first theologian of paganism, when he affirms that Hesiod did not take the trouble to search for the origin of chaos in the truth of a creator god. ${ }^{41}$ Anyway, Prudentius also expresses the ab aeterno generation of the Word with equivalent formulas, like de natus ante mundi exordium, which appears in other verses of Cathemerinon. ${ }^{42}$

Out of Prudentius' writings, a passage by Arnobius the Younger in his theological dispute with Serapion (mid-fifth century) allows us to see that every descriptive element on divinity in C. Symm. II.95-96 -being prior to time; no beginning; endlessness; creation of the world- does appear in the description of Christ's divine nature:

Verbum quod erat antequam mundus esset, uerbum quod non est a principio, sed in ipso principio semper fuit, uerbum quod caret initio, sed est ipsum initium, uerbum quod non subiacet tempori uel atomo uel momento uel puncto, sed est omnium creator. ${ }^{43}$

To sum it up, in view of the above prudentian parallels, we can see that the expressions used by our author in C. Symm. II.95-96 refer to a divine entity whose eternity is described in formulae evoking the deus verus of C. Symm. I.325-327 and the Deus Sabaoth of Cath. 4.7-9, but they do find more connections with iuncturae uerborum in other writings (Apoth. 264-267; Cath. 12.37-40) related to the Word or Christ. These formulae do also appear in Christological writings, like the one by Arnobius in his Conflictus.

Besides, both loci prudentiani (in Cathamerinon) linked by academics to Proverbs 8.22-29 identify Wisdom -or Christ- developing its creative task without leaving the bosom or power of the Father. None of these references show lexical similarities with our writing, but they make clear that Prudentius associated the eternity of divine Wisdom to the creation of the world. In 11.17-32 the one who is called Sophia when in the heart of the Father leaves His bosom to, now as Verbum prolatum, undertake the creation of heaven, light and time governing the Earth's orb, all with God's own might, "for the Word is God" (nam Verbum Deus), an expression also evoked in John 1.1:

ex ore quamlibet patris sis ortus et uerbo editus, tamen paterno in pectore sofia callebas prius.

in pagan poetry. There is, for instance, Ovidius' Metam. 1.5-7: Ante mare et terras et [...] caelum unus erat toto naturae uultus in orbe, quem dixere Chaos, rudis indigestaque moles; Lactantius definition in Inst. 1.5.8 seems to be inspired in Ovidius: Caos est rudis inordinataeque materiae confusa congeries. 41 Lact. Inst. 1.5.8-10.

42 Cath. 9.10-12 [Christus] Corde natus ex parentis ante mundi exordium,| alfa et $\omega$ cognominatus, ipse fons et clausula| omnium quae sunt fuerunt quaeque post futura sunt.

43 Arnob. Confl. 2.21 (Daur, CCSL 25 A, 43-173). 


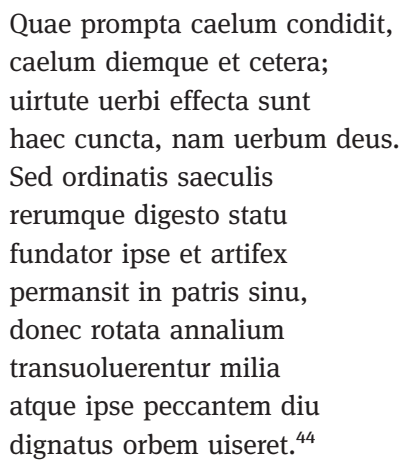

In the second passage, related to Proverbs 8.22-29, Christ -entitled omniparens, father of all things created- wields His power in the bosom of the Father before stars, earths and seas came into being (Cath. 3.1-5):

O Crucifer bone, lucisator, omniparens, pie, uerbigena, edite corpore uirgineo, sed prius in genitore potens, astra, solum, mare quam fierent. ${ }^{45}$

Even though scholars are not pointing to any reference for Colossians 1.17 in Prudentius' poetry -but the one by Brown, as already mentioned-, there are other non-prudentian writings where we can find the formulae used by our author in the verses under our scrutiny. These include, but are not limited to, the case of Faustinus the Luciferian, who identifies Christ -described by Paul as ipse est ante omnes- with the Wisdom that intervenes in creation (Psalm 103) in order to affirm the eternity of the pre-existing Christ; He, being prior to creation, is its beginning and also its creator:

Ergo ipse semper est, per quem et in quo omnia facta sunt. Sed et hymnidicus cantans ait: omnia in sapientia fecisti (Ps 103.24 LXX). Non tamen ipsam dixit factam esse sapientiam, quia et apostolus, cum dicit: et ipse est ante omnes (Col 1.17), factum negauit. Si enim eum qui non erat, factum credi uoluisset, ita posuisset: 'et ipse factus est ante omnes'; at cum dicit: 'et ipse est ante omnes', omnibus dedit initium, quorum anterior, immo et factor est; ipse uero sine initio est, qui ante omnes non factus sed esse memoratur. ${ }^{46}$

44 For Cath. 11.17, cf. Cunningham (1966): Prov 8.22; Guillén (1959): Prov 8.22; Io 1:1-2; for Cath. 11.21, cf. Cunningham (1966): Prov 8.27-30; Guillén (1959): Prov 8.27ss.; Io 1.1-3; for Cath. 11.23, cf. Guillén (1959): Io 1.1; for Cath. 11.28, cf. Guillén (1959): Io 1:18.

45 For Cath. 3.5, cf. Cunningham (1966), Rivero (1997): Prov 8.22-30. A novel interpretation of the value of crucifer, lucisator y uerbigena can be read in the article by Patricio de Navascués in this same volume.

46 Faust. Lucif. De fide contra Arianos 5.20 (Simonetti, CCSL 69, 295-353). 
This text by Faustinus shows that Colossians 1.17 is included in the scriptural arguments used for defending the consubstantiality of the Son with the Father, His generation before time, and His active presence in creation. It also allows us to justify considering Colossians 1.17 as an hypotext for our verses via formal parallels (sine initio; anterior) with C. Symm. II.95-96.

As already shown above, the loci prudentiani where Proverbs 8:22-29 appears as an hypotext associate the idea of creation to that of the eternity of the Wisdom or Word of God. Aside from Prudentius' poetry, we can also find other writings where expressions similar to those in C. Symm. II.95-96 are used, and they have as biblical basis Colossians 1.17; they also put in relation the eternity of the pre-existing Christ with His creative activity.

Last, in another non-prudentian writing, we will find again the key ideas of $C$. Symm. II.95-96, now sustained -among others- by quotations of Col 1.17 and Prov 8.22-29. In an anti-Arian context, in order to prove that the Son is of the same nature than the Father (de patris substantia), Gregory of Elvira provides a list of characteristics of the Word, as His eternity (nihil enim sine initio nisi solus deus), ${ }^{47}$ from which His being the firstborn of all creation derives (Col 1.15); an eternity inextricably shared with the Father, ${ }^{48}$ because He comes from His bosom; ${ }^{49}$ being eternal, He is true God. ${ }^{50}$ Gregory also explains that the Son is named Wisdom because of His being sapientia patris, sapientia dei, sapientia ineffabilis; in order to sustain this claim, he relies on Proverbs $8.22 .{ }^{51}$ As for the attributes of eternal Wisdom in this biblical passage, Gregory points out that initium should be understood as an operating, creative movement (initium motus operis alicuius ostendit), and deducts that both the strength and might of God's Wisdom are known through the effect of His works (de effectu operum suorum uirtus eius et potentia nosceretur), so that man can recognize the creator through the creatures (conditorem de conditis). ${ }^{52}$ Gre-


est ex nullis extantibus, ut idem arius tradidit; sublato enim eo, quod pater est, undecumque fuerit filius, necesse est, ut et initium ex nihilo et ortum ex tempore habeat; nihil enim sine initio nisi solus deus. 48 Greg. Illib. Fide 226.220 (Bulhart, CCSL 69) Ac proinde cuius origo principium non habet, sempiternus cum patre credendus est, quia nec pater potest umquam sine filio nominari nec filius sine patre uocari; ac per hoc semper filius, quia semper pater.

49 Greg. Illib. Fide 226.209 (Bulhart, CCSL 69) Igitur quod in principio erat, semper fuisse credendum est, sed nec aliunde esse, quam ex eo qui principium non habet, id est, de corde patris, quia eructauit, inquit, cor meum uerbum bonum.

50 Greg. Illib. Fide 227.227 (Bulhart, CCSL 69) Quod deus est, semper est, ne si semper non fuerit, uerus deus esse non possit, sicuti et in sophiae nomine, quia secundum apostolum ipse est sapientia patris, ego, inquit, ex ore altissimi prodiui.

51 Greg. Illib. Fide 227.234 (Bulhart, CCSL 69) Haec est illa sapientia ineffabilis, quae initium uiarum dei apud salomonem uel condita uel genita uel creata describitur; quam tamen sic conditam dicit, ut semper eam cum deo fuisse ostendat.

52 Greg. Illib. Fide 227.247 (Bulhart, CCSL 69) Creata est ergo sapientia, immo genita, non sibi, quae semper erat, sed his, quae ab ea fieri oportebat, ut quia quanta et qualis esset sciri non poterat, de ef- 
gory ends with a profession of faith in Wisdom, author and creator of the universe, who is the Son of God, by whom and in whom everything exists; this upholds Gregory on the basis of Colossians $1.16-17^{53}$ This passage by Gregory of Elvira shows that Col 1.17 and Prov 8.22-29 can both co-exist as scriptural substrate for the distich C. Symm. II.95-96, where divine eternity - expressed by the absence of beginning and end -, priority to formless matter, and creation of the world are the characteristics defining the nature of the God revealed by faith.

Nevertheless, an unanswered question remains. Even though diuinae res ${ }^{54}$ sets the context for those characteristics present in C. Symm. II.95-96, the link with deus verus in C. Symm. I.325-327 does not make clear whether Prudentius is alluding in both cases to God Father; something which becomes more likely when considering Cathamerinon 4.7-9, a passage where the same notions on divinity than those in $C$. Symm II.95-96 are undoubtedly addressed to Deus Sabaoth.

Therefore, we intend to consider the plausibility of the existence of two biblical hypotexts on the Son (be it as Wisdom of the Father, Word of God or pre-existing Christ) for this passage, where Prudentius describes the nature of God in the context of a dialogue against a fervent pagan like Symmachus. The answer to this question will be preceded by the solution to another issue: is it possible to admit, against an insufficient knowledge of God by man's sole strengths -the one proposed by Symmachus-, the description of God's nature as revealed by faith applying characteristics not entirely unsuitable for the Father, but more related to the Son, Wisdom of God, begotten before time and creator of cosmos? In other words, is there an explanation for Prudentius speaking of the deus verus to the pagan Symmachus, showing him the nature of the pre-existent Word, creator of everything by will of the Father without leaving His bosom? This is, why Prudentius, against Symmachus' pagan polytheism, does not provide arguments defending an unspecific monotheism, but reasons from the specific perspective of the sola fides christiana?

It could be argued that the aforementioned questions are pointless, because, in fact, Prudentius is answering from an undefined monotheistic point of view; against Symmachus' polytheism, he provides a generic perspective on a supreme, eternal god, maker of the cosmos and even ex nihilo creator of formless matter (chaos), out of which he models the beauty of the visible universe. Our text would perfectly fit the deus verus in C. Symm. I.325-327; besides, formal coincidences with Apoth. 264-267 and Cath. 12.37-40 (related to the Word) could be explained assuming

fectu operum suorum uirtus eius et potentia nosceretur, ut dum conditorem de conditis aestimamus, tunc magis timeremus, cum facta miramur.

53 Greg. Illib. Fide 228.262 (Bulhart, CCSL 69) Haec est, inquam, illa sapientia dei, quae dicit: ego ex ore altissimi prodiui, uniuersitatis conditrix et effectrix, id est filius dei, per quem omnia et in quo omnia, quia ut apostolus dixit: in ipso constituta sunt uniuersa in caelis et in terra, uisibilia et inuisibilia, siue throni siue dominationes siue uirtutes siue principatus siue potestates: omnia per ipsum et in ipso condita sunt et ipse est ante omnia et omnia in ipso constant.

54 Cf. C. Symm. II.94. 
that Prudentius was presenting the true doctrine in a vague way. From this perspective, it would be much the same for our author writing about the Father in Contra Symmachum using lexical materials also employed by him in other poems designing the $a b$ aeterno begotten Word, or about the pre-existing Son who later would be incarnated in History.

But there is another plausible explanation. In order to lay its basis, we must turn to other writings of the second-generation Christian apologetics, those of Lactantius. In his masterpiece, Diuinae Institutiones, against the premises of polytheism he opposes the truth of God as comprised in the theology of creation. As aforementioned, he states that the chaos mentioned by Hesiod is the pre-existing matter created by the God to whose might everything is subjected (deus fecit cuius potestati subiacent omnia) ${ }^{55}$ But before beginning with creation he made a spirit like Himself, endowed with the same virtues as God the Father, who resorted to Him as a counselor and author in the scheduling, arrangement and execution of everything. ${ }^{56}$ Therefore, for Lactantius the first step in the theology of creation starts with the generation of the Word, the holy and incorruptible spirit named Son.${ }^{57}$ His existence had been commented even by Hermes Trismegistus and the Sybils, ${ }^{58}$ but is expressed in words of Solomon in Proverbs 8:22-29. This spirit intervenes actively in the creation of the world. ${ }^{59} \mathrm{He}$ is very mighty, very dear to God, and not only is He born before the universe, but also ordered it with His intelligence and made it with His might. ${ }^{60}$

55 Lactant. Inst. I.5.8: potuit Hesiodus, qui deorum generationem unius libri opere conplexus est: sed tamen nihil dedit non a deo conditore sumens exordium, sed a chao, quod est rudis inordinataeque materiae confusa congeries, cum explanare ante debuerit chaos ipsum unde quando quomodo esse aut constare coepisset; Inst. II.8.8: nec audiendi sunt poetae, qui aiunt chaos in principio fuisse, id est confusionem rerum atque elementorum, postea uero deum diremisse omnem illam congeriem singulisque rebus ex confuso aceruo separatis in ordinem que discriptis instruxisse mundum pariter et ornasse. The idea for my demonstration is inspired by Garuti's intuitions (1996) 169.

56 Lactant. Inst. II.8.3: cum esset deus ad excogitandum prouidentissimus, ad faciendum sollertissimus, antequam ordiretur hoc opus mundi, quoniam pleni et consummati boni fons in ipso erat, sicut est semper, ut ab eo bonum tamquam riuus oreretur longe que proflueret, produxit similem sui spiritum, qui esset uirtutibus patris dei praeditus; Inst. II.8.7: exorsus igitur deus fabricam mundi illum primum et maximum filium praefecit operi uniuerso eoque simul et consiliatore usus est et artifice in excogitandis ordinandis perficiendisque rebus, quoniam is et prouidentia et ratione et potestate perfectus est; de quo nunc parcius, quod alio loco et uirtus eius et nomen et ratio enarranda nobis erit.

57 Lactant. Inst. IV.6.1 Deus igitur machinator constitutorque rerum, sicut in secundo libro diximus, antequam praeclarum hoc opus mundi adoriretur, sanctum et incorruptibilem spiritum genuit, quem filium nuncuparet.

58 Lactant. Inst. IV.6.3.

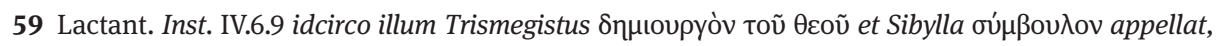
quod tanta sapientia et uirtute sit instructus a deo patre, ut consilio eius et manibus uteretur in fabricatione mundi.

60 Lactant. Inst. IV.7.1: iste tam potens, tam deo carus [...] cuius prima natiuitas non modo antecesserit mundum, uerum etiam prudentia disposuerit, uirtute construxerit. 
The theology of creation found in the apologetical writings represented by Lactantius enables us to discover that the nature of an eternal god creator is explained by the inspired or revealed news rendered by Scripture in Proverbs 8.22-29. When unspecifically alluding God in such contexts, this apologetical tradition implicitly takes into account the $a b$ aeterno generation of the Word, visible Wisdom endowed with creative power by the invisible Father. These passages by Lactantius show that the procedure of presenting notions specific to the Christian deus uerus, revealed by faith, is -even in the context of a dialogue with polytheistic paganism- a discursive device which could also have been employed by Prudentius in his disputation with Symmachus. ${ }^{61}$ Generically alluding the deus verus in C. Symm. I.325-327, as well as stating His eternal, creative nature in C. Symm. II.95-96 cannot be explained, not so much due to a lack of dogmatic specificity in a poetical context, but rather because there is a conscious lexical unspecificity overlaying the specificity of the sola fides, according to which there is no question of an eternal, creator God out of the implicit reality of the Son of the Father, the ab aeterno begotten Word, who, without leaving the bosom of the Father, participates in the creation of the world, as shown by the presence of Proverbs 8.22-29 in the poetry of Prudentius.

\section{Bibliography}

Arévalo (1789): F. Arevalus, M. Aureli Clementis Prudenti, v. c., Carmina. Tomus secundus, Romae. Bergman (1926): Io. Bergman, Aurelii Prudentii Clementis Carmina, Vindobonae - Lipsiae.

Brown (2003): M.P. Brown, Prudentius' Contra Symmachum, Book II. Introduction, Translation and Commentary, Newcastle.

Cunningham (1966): M.P. Cunningham, Aurelii Prudentii Clementis Carmina, Turnholti

Cunningham (1983): M.P. Cunningham, Aureli Prudenci Clement. Contra Simmac. Text revisat per

Maurice P. Cunningham, Barcelona.

Dressel (1860): A. Dressel, Aurelii Prudentii Clementis quae exstant Carmina, Lipsiae.

Evenepoel (1981): W. Evenepoel, “Prudentius: ratio and fides", in: L'antiquité classique 50, $318-327$.

Fernández Vallina (1989): E. Fernández Vallina, “¿Vino nuevo en odres viejos? Expresión de un conflicto a principios del siglo V", in: Helmantica 40, 245-254.

Garuti (1996): G. Garuti, Prudentius. Contra Symmachum, L'Aquila - Roma.

Guillén (1959): J. Guillén, Aurelio Prudencio. Obras completas, Madrid.

Kayser (1881): J. Kayser, Beiträge zur Geschichte und Erklärung der ältesten Kirchenhymnen, Paderborn.

Lanfranchi (1898): V. Lanfranchius, Aurelii Prudentii Clementis Opera. Volumen II, Augustae Taurinorum.

61 It is possible that Prudentius took his argumentative outline from Lactantius. We may think so not only on account of these passages of Inst. IV, but also -among other things- because of the allusion to the theology of the temple inscribed in the defense of true worship in Inst. VI (Inst. VI.25.3; 15). Prudentius resorts to the doctrine of inhabitation of the human soul by God against Symmachus' claims, in order to disprove the need of material temples for worshipping God: templum mentis amo, non marmoris (C. Symm. II.249). 
Langen (1497): R. von Langen, Opera Aurelii Clementis Prudentii, Deventer.

Lavarenne (1992): M. Lavarenne, Prudence. Tome III. Psychomachie. Contre Symmaque, Paris.

Middeldorpf (1823): H. Middeldorpf, Commentatio de Prudentio et theologia Prudentiana,

Vratislaviae.

Moreno (2002): J.L. Moreno Martínez, “Aurelio Prudencio y el debate sobre el altar de la Victoria”, in: Kalakorikos 7, 79-102.

Orbarius (1845): Th. Orbarius, Aurelii Prudentii Clementis. Carmina, Tubingae.

Ortega and Rodríguez (1981): A. Ortega, A. Rodríguez, Obras completas de Aurelio Prudencio, Madrid.

Pascual (1976): J. Pascual, Antropología de Aurelio Prudencio, Roma.

Rivero (1997): L. Rivero, Prudencio. Obras II, Madrid.

Shanzer (1989): D. Shanzer, “The Date and Composition of Prudentius's Contra orationem Symmachi libri”, in: Rivista di Filologia e di Istruzione Classica 117, 442-462.

Thomson (1953): H.J. Thomson, Prudentius II, London - Cambridge, Massachusetts.

Tränkle (2008): H. Tränkle, Prudentius. Contra Symmachum - Gegen Symmachus, Turnhout. 
